THE EMBODIED EYE 
The publisher gratefully acknowledges the generous support of the Art Endowment Fund of the University of California Press Foundation. 


\section{THE EMBODIED EYE}

RELIGIOUS VISUAL CULTURE

AND THE SOCIAL LIFE OF FEELING

David Morgan

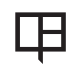

UNIVERSITY OF CALIFORNIA PRESS

Berkeley Los Angeles London 
University of California Press, one of the most distinguished university presses in the United States, enriches lives around the world by advancing scholarship in the humanities, social sciences, and natural sciences. Its activities are supported by the UC Press Foundation and by philanthropic contributions from individuals and institutions. For more information, visit www.ucpress.edu.

University of California Press

Berkeley and Los Angeles, California

University of California Press, Ltd.

London, England

(C) 2012 by The Regents of the University of California

\section{Library of Congress Cataloging-in-Publication Data}

Morgan, David, 1957-.

The embodied eye : religious visual culture and the social life of feeling / David Morgan.

$$
\text { p. } \mathrm{cm} \text {. }
$$

Includes bibliographical references and index. ISBN 978-0-520-27222-4 (cloth : alk. paper)

ISBN 978-0-520-27223-I (pbk. : alk. paper)

I. Vision-Religious aspects. 2. Senses and sensationReligious aspects. 3. Experience (Religion). 4. Psychology, Religious. 5. Art and religion. I. Title.

$$
\begin{aligned}
& \text { BL53.M66 } 2012 \\
& 204.2019-d_{c 23}
\end{aligned}
$$

2011022765

Manufactured in the United States of America
$\begin{array}{llllllllll}21 & 20 & \text { I9 } & \text { I8 } & \text { I7 } & \text { I6 } & \text { I5 } & \text { I4 } & \text { I3 } & \text { I2 }\end{array}$
IO $\quad 9 \begin{array}{lllllllll} & 9 & 7 & 6 & 5 & 4 & 3 & 2 & \text { I }\end{array}$

In keeping with a commitment to support environmentally responsible and sustainable printing practices, UC Press has printed this book on Rolland Enviroıoo, a Ioo\% post-consumer fiber paper that is FSC certified, deinked, processed chlorinefree, and manufactured with renewable biogas energy. It is acid-free and EcoLogo certified. 
To my father, who taught me not to rest where contentment bids, and to my mother, who would have preferred it, but never complained. 
This page intentionally left blank 